\title{
Tomaculous neuropathy
}

Nerve biopsy from a woman aged 21 with hereditary liability to pressure palsies.

Top left: Teased fibres showing several tomacula (arrows). Tomacula (literally "little sausages") were most frequently seen at paranodes and incisures of Schmidt-Lanterman. Scale bar $=50 \mu \mathrm{m}$.

Top right: Electron micrograph of a transverse section through a tomaculum, at an incisure of Schmidt-Lanterman. The axon, a, is slightly compressed by infolded loops of myelin. Scale bar $=1 \mu \mathrm{m}$.

Bottom: Electron micrograph of a transverse section through a tomaculum. Note the regular decompaction of the adaxonal layers of the myelin sheath: this pattern of decompaction was most typically associated with incisures of Schmidt-Lanterman, but was also seen in paranodal myelin. Scale bar $=0.5$ $\mu \mathrm{m}$.

Inset: Decompacted adaxonal myelin, showing separation of major dense lines. The electron-lucent material between the lines may be Schwann cell cytoplasm. Scale bar = $0.5 \mu \mathrm{m}$. $\mathrm{a}=$ axon; $\mathrm{m}=$ myelin; $\mathrm{s}=$ abaxonal Schwann cell cytoplasm.

$S$ M HALL

Division of Anatomy and Cell Biology, UMDS, Guy's Hospital, London, UK

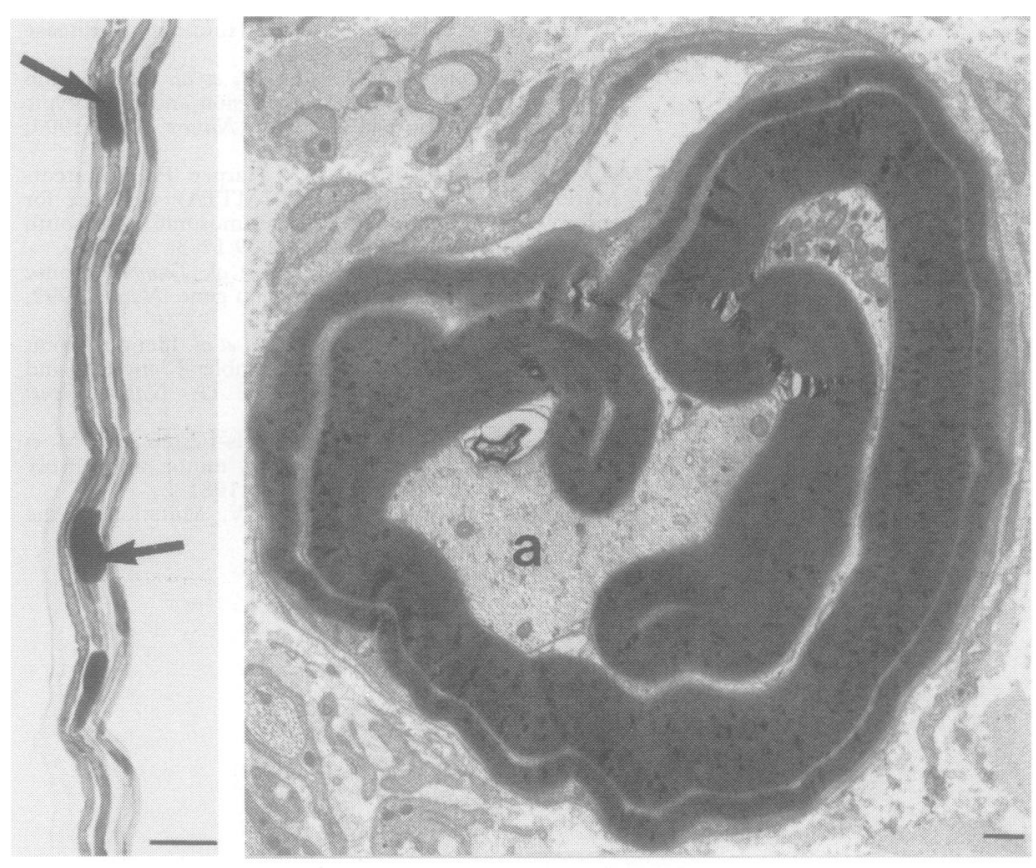

